\title{
Waging Love from Detroit to Flint
}

\author{
Michael Doan, Shea Howell and Ami Harbin
}

Over the past five years the authors have been working in Detroit with grassroots coalitions resisting emergency management. ${ }^{1}$ In this essay, we explore how community groups in Detroit and Flint have advanced common struggles for clean, safe, affordable water as a human right, offering an account of activism that has directly confronted neoliberalism across the state. We analyze how solidarity has been forged through community organizing, interventions into mainstream media portrayals of the water crises, and the articulation of counternarratives that center the experiences, needs, and collective power of those most directly affected. While our rootedness in Detroit leads us to focus primarily on the experiences of activists based there rather than in Flint, we insist throughout that the experiences, resistance, and aspirations of these communities are best understood as interconnected and mutually empowering.

\section{Resisting Emergency Management in Michigan}

Detroit has provided water to the City of Flint since 1967, the year of the Detroit Rebellion. Within a few years Detroiters had elected Coleman A. Young, one of the first and strongest African American mayors in the United States. Young's election reverberated across the country. Many whites living in the Southeast Michigan region perceived emerging African American political power as a threat and, over the next several decades, abandoned cities for suburbs (Sugrue 2005). During the 1970s, nearly 250,ooo jobs left Detroit and the city lost onefifth of its population. Over the next decade, black unemployment had risen to 34 percent and the Metro Detroit region had the largest income differential between city and suburbs of any major metropolitan area in the country. Oakland and Macomb Counties welcomed whites fleeing from Detroit while Genesee County welcomed scores more from Flint. Suburban, white residents were concerned that their water supply had been left in the hands of a majority

1 The following chapter is an expanded version of the 2019 article by Sharon Howell, Michael D. Doan, and Ami Harbin entitled "Detroit to Flint and Back Again: Solidarity Forever" that was published in Critical Sociology 45(1): 63-83. 
black city with a steadfast leader. Young famously warned Detroiters not to give up control of the Detroit Water and Sewerage Department (DWSD), as Oakland County Executive L. Brooks Patterson had been attempting to wrest control of Detroit's water system for decades (Cramer 2015).

Emergency management and the Detroit bankruptcy process would eventually provide a convenient means of seizure. Over the past thirty or so years, the State of Michigan has adopted a series of statutes for dealing with municipal fiscal distress by interfering in the affairs of fiscally troubled municipalities. In March 2011, two months after Governor Rick Snyder took office, the Republican-controlled state legislature passed Public Act (PA) 4, replacing Emergency Financial Managers (EFM s) with Emergency Managers (EM s) and significantly extending the scope of an EM's powers. PA 4 not only allows an EM to assume the responsibilities of all local elected officials, but grants them "quasi-judicial powers related to breaking contracts" (Scorsone 2014: 39). The law empowers EM s to modify, terminate, and ban entry into collective bargaining agreements; contract out public services and sell off public assets; and dismiss public officials, set aside minimum staffing requirements, and consolidate or dissolve local departments. PA 4 enables the suspension of a city's charter and strips all local elected officials of their powers, imposing the authority of the state through an EM accountable solely to the governor, effectively stripping city-dwellers of their citizenship rights.

Such political disenfranchisement has disproportionately impacted workingclass communities of color, particularly African Americans. Between 2007 and 2013, "51.7 percent of black Michigan residents had been subjected to emergency intervention, while only 2.7 percent of their white counterparts were similarly affected" (Kirkpatrick and Breznau 2016). When Kevyn Orr was appointed as Detroit's EM in 2013, 57 percent of the state's African American population were living without political representation in either their municipality or school district. As residents of Flint, and then Detroit, found themselves under the control of unelected technocrats, forces that had long been stymied by effective African American leadership surfaced to accomplish mutually reinforcing goals. For Flint, emergency management became a vehicle for ending the half-century connection to DWSD amidst plans to shift the water supply to the emerging Karegnondi Water Authority (KWA). For Detroit, emergency management facilitated the establishment of a second regional authority, placing control of Detroit's water system in the hands of the suburban-dominated Great Lakes Water Authority (GLWA). Central to both decisions were the racist perceptions of mostly white suburban officials, who repeatedly cast city-dwellers as incapable of governing and standing in the way of "progress." 
Emergency management in Michigan has been resisted at every stage of its development, forcing right-wing legislators to continually refine their efforts. Opposition has included civil disobedience, petition drives, a statewide referendum, public protests, court challenges, public theater, alternative media production, and intense organizing of opposition voices and alternative forms of governance. In the wake of numerous statewide demonstrations, a petition drive carried forward by members of the Stand Up for Democracy (SUD) coalition succeeded in getting PA 4 on a referendum ballot. The law was overturned in November 2012 when 53 percent of Michigan's citizens voted it down. Nevertheless, in a lame-duck session in December of the same year the state legislature passed PA 436, which functions similarly to its widely unpopular predecessor. Appropriations were also written into the new law that shield it from public challenge, effectively making PA 436 referendum-proof.

Efforts to repeal PA 4 were both propelled by and helped inspire challenges to the constitutionality of the law. In early 2011, the Sugar Law Center for Economic and Social Justice filed a suit alleging that PA 4 violated the principle of municipal home rule, violated citizens' right to vote and petition, abolished the separation of executive and judicial powers, and forced local taxpayers to pay the salaries of state-appointed EM s. Since this first suit was rendered pointless when PA 4 was repealed, the attorneys involved filed a second suit against PA 436. Arguing before federal judges, they alleged that PA 436 violated the Voting Rights Act in addition to the US Constitution's First, Thirteenth, and Fourteenth Amendments, as well as its Due Process, Guarantee, and Equal Protection Clauses. In November 2014, a district court judge dismissed most of the charges, leaving the alleged violation of the Equal Protection Clause on the basis of race as the only one left to be tried. Instead of arguing that PA 436 was discriminatory in intent (a burden of proof that is notoriously difficult to meet), the attorneys decided to pursue an appeal via the Sixth Circuit Court of Appeals, only to have it dismissed by unanimous decision in September 2016. Since the US Supreme Court declined to consider the constitutionality of the law in October 2017, the options for mounting constitutional challenges against emergency management have all but been exhausted. As Flint-based scholar-activist Benjamin Pauli points out, though, "the legal battles against PA 4 and PA 436 may have had their most important effects outside a legal context," insofar as they diminished the standing of emergency management in "the court of public opinion," perhaps even helping to "generate de facto constraints on the exercise of state power" (Pauli 2019: 114). 
In 2013, Governor Snyder declared that the City of Detroit was in a state of "financial emergency." He appointed Kevyn Orr, a bankruptcy attorney, to replace all duly elected officials and govern over the city as its Emergency Manager. After filing for the largest Chapter 9 bankruptcy in US history in July of the same year, Orr listed DWSD as an asset in the bankruptcy proceedings, saying he planned to sell off the water system to reduce the city's debt. In order to make the water department more attractive to buyers, Orr ordered a crackdown on overdue residential water bills in an effort to collect $\$ 90.3$ million in delinquent fees. Following Orr's order, DwsD signed a two-year, \$5.6 million contract with Homrich Wrecking Company, authorizing the private contractor to conduct turnkey disconnections at a rate of between 1,500 and 3,000 homes per week. Homrich was directed to shut off water to all households with a bill of more than $\$ 150$ or an arrearage of greater than 6o days (Rall 2018). Households were immediately subject to shutoffs without any advance notification or warning. In March 2014, Homrich began carrying out Orr's mass water shutoff campaign, which targeted some 100,00o Detroit residents, or about one sixth of the city's population. Red Homrich trucks with DwSD logos plastered on their doors could be seen creeping up and down neighborhood blocks on a daily basis. Homrich workers strolled from house to house, spraying a bright blue line on each spigot they turned.

Homrich trucks rolled onto Charity Hicks' block early in the morning of May 16, 2014. Already up for the day, Hicks started running from door to door, waking up her neighbors and telling them to fill up their bathtubs, pots, and pans. When Homrich workers arrived at her house she was waiting out on her front lawn. Knowing that she had two more days left to pay her bill, Hicks demanded that the men present an official shutoff order, only to be met with a shrug-all they could produce was a list of addresses. When Hicks refused to let the men turn off her water, the argument evolved into a progressively louder and, eventually, physical confrontation, prompting Hicks to call police to the scene. In a strange, if predictable, reversal, the cops-both whiteplaced Hicks - a black woman and environmental justice activist known for her fierceness and determination-under arrest, effectively punishing her for taking a stand in defense of her water. As they drove her to the Central Detention Center, the cops threw Hicks' keys and phone out on the front lawn and left her house unlocked. Her husband would later return home to this scene, frightened and confused. It was only after filing a missing person report with the police that he would learn that it was the police who had made her disappear. 
For her simple and dignified act of resistance, Hicks was quickly recognized as the "Rosa Parks of the Detroit Water Struggle" (Wiley-Kellermann 2017: 105). Upon her release from jail, she shared her story with fellow activists gathered at St. Peter's Episcopal Church, urging her comrades to "wage love" in the water struggle already intensifying across the city. The phrase quickly caught on and would later be invoked as a way of honoring Hicks in the wake of her tragic passing. Hicks was struck down by a car in a hit-and-run as she waited for a bus in New York City while on her way to speak about the Detroit water crisis at the 2014 Left Forum. After spending the next few weeks in a coma, she joined the ancestors in early July.

As Hicks' example shows, the methods Detroiters have devised to cope with waves of mass water shutoffs reflect a persistence in finding ways to survive with dignity. Some people have simply turned their water back on, a practice that became so widespread that the water department began levying strict fines and permanently shutting off offenders. Others share water from house to house, stringing garden hoses across alleys and through windows. Still others open their homes to share bathing, cooking, and laundry facilities. Prior to the start of the 2018 school year, neighborhood schools opened early and closed late so that children could bathe and wash clothes. Careful to frame these activities in ways that would not further endanger families (as child protective services is authorized to remove children from homes without water), teachers developed tactical responses using school resources to directly support children.

\section{Stop the Shutoffs!}

Building on methods devised at the neighborhood level, Detroit's water warriors have responded to mass shutoffs with a range of strategies and a diversity of tactics. Some immediately recognized the fight for water access led primarily by black women as the next phase in the long civil rights struggle, seeking structural change through a combination of direct action, courtroom battles, and efforts to push progressive legislation. Other, especially younger activists have been less optimistic about creating meaningful change through the existing political system, which they regard as having long been broken beyond repair. While differing tendencies continue to exist in creative tension, community activists have worked to create a movement that challenges the existing system on all fronts, integrating "both efforts to influence the workings of the current political system and efforts to create independent systems that will supplant that system" (Rall 2018: 119). Specific tactics have included water 
deliveries to meet immediate needs, acts of civil disobedience, public protests and press conferences, teach-ins and public forums, a people's tribunal, lawsuits, video clips for social media, and documentary films.

The dramatic escalation in shutoffs was initially met with organized resistance in the streets as well as efforts to secure a moratorium through direct action and in the courts. Marches were organized every Friday out front of the downtown DwsD building, where Detroiters could be heard chanting, "Stop the shutoffs!" "Whose water? Our water!" and "Water is a human right - fight, fight, fight!" Dubbed "Freedom Fridays," the gatherings invoked the spirit of the "Moral Mondays" movement already underway in North Carolina. Building on the momentum created by these marches, a series of higher profile actions helped draw more media attention to the shutoffs. From July 17 to 21, 2014, the Netroots Nation conference took place at the Cobo Center in downtown Detroit, opening an opportunity for Detroit organizers to amplify the work underway on the ground. The Netroots conference featured panels with frontline activists from Detroit and Flint, including a keynote focused on resisting shutoffs. Upon learning of the public health implications of the shutoffs, National Nurses United (NNU) - the largest union and professional association of registered nurses in the country - called a march through downtown Detroit on July 18 and released a statement declaring a public health emergency in the city. Union members were joined on the streets by hundreds attending the Netroots conference, including actor and water rights activist Mark Ruffalo. In collaboration with Detroit organizers, they created a media spectacle that drew national attention to the situation.

The visibility of the march also created an opening for Detroit activists to engage in a strategically timed act of civil disobedience. While the action involved placing bodies on the gears of the city's shutoff machine to temporarily halt harms, those involved would also challenge the conscience of city officials and residents through the ensuing trial. On July 18, 2014, the group that came to be known as the "Homrich 9" (Marian Kramer, Bill Wiley-Kellermann, Baxter Jones, Joan Smith, Jim Perkinson, Hans Barbe, David Olson, Marianne McGuire, and Kim Redigan) were arrested and charged with disorderly conduct for blocking Homrich trucks from leaving their Detroit base to execute shutoffs. After demanding a jury trial, hoping to tap into "the last vestige of democracy" in a city under dictatorial rule, the defendants faced several delays and motions secretly crafted by law department officials in an attempt to prevent the jury from issuing a verdict (Wiley-Kellermann 2017: 153). The powers that be seemed especially wary of the optics of a jury expressing their collective opinion in response to the necessity defense advanced by the defendants, 
who claimed that the act of blocking the Homrich trucks, though illegal, was necessary to prevent serious harm. Although the jury was ultimately prevented from expressing their assessment of the evidence, the Homrich 9 were never convicted for their act of safeguarding. After nearly three years of court proceedings that included a highly controversial emergency stay, in July of 2017 Judge Ronald Giles of the 36 th District Court dismissed all charges, citing a lack of a speedy trial (Williams 2017).

Several victories could be claimed from the Homrich 9 saga. First, the willingness of this group of ordinary people to openly defy the law in defense of themselves and fellow Detroiters demonstrated the seriousness of the harms the state was inflicting on entire neighborhoods. Their effort to expose and halt state violence underscored the consequences of usurping local democracy, challenging people of conscience to act directly to end the shutoffs. Second, the defendants refused a guilty plea that the state would have been pleased to solicit, mounted a compelling necessity defense, and provoked government officials into interfering with the trial. Had the jury been allowed to issue a verdict, a significant precedent would have been set, perhaps opening the door to further disobedient acts and further undermining the legitimacy of emergency management. Third, as reports of the Homrich g's action merged with national news stories highlighting the NUN march, city officials were forced to respond with more than words of reassurance. The city instituted a temporary moratorium on shutoffs effective July 21, 2014. Although the moratorium lasted for just over a month, it demonstrated that a small group of Detroiters stripped of their citizenship rights could intervene directly, thwarting the tyranny of emergency management armed only with their bodies and appeals to conscience.

The Homrich 9 saga also strengthened parallel efforts to secure a more lasting moratorium through the courts. On July 21, 2014, activist-lawyer Alice Jennings of the National Conference for Black Lawyers ( $\mathrm{NCBL}$ ), working with a broad coalition of grassroots organizations including the People's Water Board (РWв), We the People of Detroit (WPD), and Detroiters Resisting Emergency Management (D-REM), filed a civil rights case requesting that the bankruptcy court halt the shutoffs for a period of six months. After refusing to grant the moratorium, Judge Steven Rhodes, who was charged with overseeing the bankruptcy process, justified his decision by claiming that, "Detroit cannot afford any revenue slippages" (Lambert 2014). Undeterred, Jennings took the case to the Sixth Circuit in October 2015. After nearly two years on the case, however, federal judges were unwilling to overrule Rhodes' decision, which meant that ending the shutoffs through the courts would be far more difficult than many had hoped. 
Back in May 2014, Charity Hicks had attended a conference in Detroit that she and other PWB members organized with Maude Barlow-renowned Canadian water rights activist and co-founder of the Blue Planet Project (BPP) who played a pivotal role in getting the United Nations (UN) to declare a human right to water. Upon hearing Hicks' story, Barlow insisted they draft a report requesting UN support (B PP 2014: 7). In response to the report, the UN Office of the High Commissioner for Human Rights issued a press release stating that Detroit's water rates were relatively high and that widespread poverty made these bills "unaffordable for a significant portion of the population" (OHCHR 2O14). "Disconnections due to non-payment are only permissible if it can be shown that the resident is able to pay but is not paying," said Catarina de Albuquerque, Special Rapporteur on the Human Right to Safe Drinking Water and Sanitation. "In other words, when there is genuine inability to pay, human rights simply forbid disconnections." Leilani Farha, Special Rapporteur on the Human Right to Adequate Housing, raised concerns about children being removed from their families by social services. "If these water disconnections disproportionately affect African Americans they may be discriminatory, in violation of treaties the US has ratified," she added (OHCHR 2014).

The UN report was further supported by testimonial evidence gathered at a Town Hall Meeting held at Wayne County Community College on October 19, 2014 (MWRO and PWB 2014; Lewis-Patrick and Cabbil 2014). Nearly 8 oo people joined the two UN representatives to hear the stories of people experiencing shutoffs, giving Detroiters an opportunity to directly shape the UN response. Detroit native Gregory Price offered the following: "I live in zip code 48204; my block was hit by foreclosures ... 2 or 3 people have lost their house for not paying water tax - they have children; they are not receiving any services/ benefits; when they receive 'help' it's a bill too high to pay-that's the payment plan! It's a lose-lose situation; I want to make sure I and my community are heard; if you can do something about it we need your help." Nichole Hill, also of Detroit, recounted how, "The water was cutoff for 8 weeks in 2014; they were steadily cutting off the whole neighborhood so there was nobody to ask for water; the whole block except 3 or 4 homes were cutoff. I have asked to dispute my bill or for a hearing; I was told I could get a hearing time in 2015 possibly; they continue to bill me; they billed me when the water was cut off; it was cutoff again in October despite supposedly being in a payment plan; the bill is over $\$ 6$,ooo; they can't explain it; I've paid $\$ 3$, ooo in the last few years" (D-REM 2014). 
The controversy over Detroit's mass water shutoffs brought into focus two opposing visions of the city, underwritten by conflicting understandings of water and what we owe each other. On the one hand, for Orr, Duggan, and the corporate establishment, water is a commodity to be bought and sold on the market. While it happens to be a good that humans need to survive, water is by no means a right to which we are entitled-like food and shelter, there is no such things as "free" water. For these reasons, access to water is and ought to be conceived as a privilege available only to those with the means to pay. (As one city official succinctly put it: "Go down to the river and get a bucket - that's your right"). On the other hand, throughout the city there has been an emerging consensus that water, which is essential to all life, should be seen as a basic human right to be held in the public trust. It is, therefore, the responsibility of local and regional governments to ensure the availability of safe, clean, affordable water for all.

As this growing consensus was channeled into organized resistance and the UN's involvement drew international media attention to what reporters started identifying as "Detroit's water crisis," a new arena of struggle was opened over perceptions of the situation on the ground. Shaping public perceptions was a difficult task for community activists owing to the pervasiveness of deeply entrenched negative attitudes towards Detroit, especially in the wealthier, whiter suburbs. The suburban view is reflected in the comments of Oakland County Executive L. Brooks Patterson, who, in the midst of the city's bankruptcy, gave an interview to the New Yorker entitled “Drop Dead, Detroit!" After explaining that he would not allow his children to go into the city for fear of crime, he responded to the question of how Detroit might fix its financial problems by saying, "I made a prediction a long time ago, and it's come to pass. I said, 'What we're gonna do is turn Detroit into an Indian reservation, where we herd all the Indians into the city, build a fence around it, and then throw in the blankets and corn'" (Williams 2014). While these comments ignited a firestorm, they were vintage Patterson, who once said of an African American Councilwoman that he would rather "own a 1947 Buick than own her." Racialized logics of corruption and incompetence have been essential to shifting public assets away from the city, as well as to denying analyses of suburban dispossession and discounting the credibility of their proponents.

Nevertheless, the seriousness of mass water shutoffs, combined with the testimony of people whose lives and communities had been disrupted, sometimes helped make the truth more compelling — or difficult to dismiss — than usual. The struggle over public perceptions of the shutoffs took the form of a 
struggle between conflicting answers to the following questions: What made the situation in Detroit a "crisis"? What sort of crisis was it? What was the central problem and how had it taken shape? Who was responsible in what ways? How could the problem be resolved? Community activists' claims about the context, causes, and harms of mass water shutoffs consistently challenged the assertions of state and local officials, uncovering myths and exposing lies. Their assessments of who and what was responsible for the crisis also prompted officials to minimize and deny their own culpability and to strategically shield from view the legal frameworks and structures within which they were all operating.

\subsection{The Official Narrative}

The narrative pushed by government officials and mainstream media pundits is that the central problem of Detroit's so-called water "crisis" is residents' refusal to pay their bills. According to this "official narrative," the failure of some residents to make timely payments has forced the water department to raise rates on all residential customers. As a result, more financially responsible residents end up paying more for water than they otherwise would, so these more responsible customers are effectively subsidizing all the delinquent ones.

Mayor Mike Duggan has been one of the chief pushers of this narrative. When it became clear that citizen outrage over the shutoffs was garnering international attention, EM Orr turned over operations of DWSD to Duggan, the then newly elected mayor. Although he had been critical of the way Orr pursued the shutoffs, Duggan defended their necessity, insisting they were justified. When he assumed responsibility for the water department in July 2014, he began claiming that, "When some Detroit residents don't pay their bills, those bills have to be paid by other Detroiters" (AlHajal 2014). By saying this, Duggan is suggesting that it is unjust for those who make timely payments to be paying extra - an added tax, as it were, to cover the debts of delinquent customers. The unspoken implication is that justice demands these delinquents be punished for harming everyone else. Far from a miscarriage of justice, then, water shutoffs are precisely what justice requires.

Writing in support of the official narrative, Nolan Finley of the Detroit News underscores the scandal of residents refusing to pay their bills: "instead of using what resources they have to cover their needs, many water customers instead have chosen to service their wants" he claims, adding that such types continue to splurge cable television and cell phones. "That's what happens when people are conditioned to think someone else is responsible for taking care of them," continues Finley. "In Detroit, the someone else is the half of residents who do pay their water bills, and this year were hit with an 11 percent increase 
that was largely necessary to cover the unpaid bills of scofflaws" (Finley 2014). Interestingly, Finley's "scofflaw" comment went to print just a day after Orr had used the same label in an interview. "Let's find the legitimate need," Orr told Detroit News reporters, "but the scofflaws and the people gaming the system, let's either bring them into compliance or not provide them with a free service. That's not fair" (Ferretti and Pardo 2014).

Appeals to fairness aside, Orr has also defended his shutoff campaign on strictly economic grounds. He has argued that clearing delinquent accounts from the water department's books is a matter of "financial necessity" for a utility aiming for solvency in the midst of a steady decline in the city's population and revenues. His decision to balance DWSD's books through the adoption of a tougher debt collection policy was based on "general business principles": the department needed to recoup millions in unpaid bills and customers needed to pay up. Besides, the decision to cut off services to delinquent customers is completely normal: it is a "decision to do what every other regulated utility does in the United States, which is, if you use water you've got to pay for it" (Ferretti and Pardo 2014).

Not only were shutoffs positioned as what justice requires and a financial necessity, but they could also be justified by their anticipated effects. According to Daniel Howes of the Detroit News, Orr's shutoff campaign was about initiating a "shift in culture"- away from frivolous spending and dependence on government largess, towards personal responsibility and financial independence. "Residents struggling to pay their water bills are not the central issue," claims Howes. "It's the culture of non-payment that afflicts those with means" (Howes 2014). "By moving to repair what's long been broken, accepted by many and exploited by some," he adds, "the department is leading its own effort to modernize a culture marked by entitlement and abandonment" (2014). Echoing Howes, Finley insists that, "This is not a humanitarian crisis"—let alone a crisis of any kind-but simply "a necessary forced reordering of priorities" (Finley 2014).

With Orr, Duggan, and their boosters taking turns in the roles of bad cop, municipal bureaucrats stepped forward to play good cop. By adding nuance that only local knowledge can provide, they worked to strengthen the official narrative. For example, instead of pinning all the blame on delinquent customers, DWSD officials added that these types have historically been enabled by a lack of serious enforcement. "There was no rigid enforcement policy or practice at the water department for years," recalls Bill Johnson, the utility's head spokesperson. "You allow the situation to languish and people think you don't care." But the water department is not solely to blame for its lax enforcement. "Some of it was under pressure from the mayor's office, some of it from 
City Council" (quoted in Howes 2014). While DwsD's reluctance to "get serious" may have sent the wrong message, the obvious implication is that it is long past time to implement the more "rigid" debt collective policy that past officials were too permissive to support. Were it not for the intervention of an Emergency Manager, Johnson implies, locally elected officials may never have had the guts to do what justice requires.

Tellers of the official narrative invite us to imagine entitled, "scofflaw" Detroiters talking on iPhones while water flows for free. Meanwhile, their neighbors end up footing the bill one way or another, and everyone's bills keep rising because of this "culture of non-payment." It's only fair that Orr is finally giving these crooks what they deserve and forcefully reforming their backward culture. For those who truly deserve help with their bills, the water department has made assistance programs available: "All they need to do is call," Orr assured reporters (Ferretti and Pardo 2014). Since these programs are funded largely through private donations, more generous donors are needed-at least, that is, so long as the bad Detroiters keep causing everyone's water rates to rise, and the good ones keep struggling to afford them. To sum up the official narrative: no "crisis" here, just a few undisciplined customers adrift in cultural backwardness. Shutoffs may seem harsh, but nothing less will bring justice and order to the city.

\subsection{Reframing Detroit's Water Crisis}

By way of contrast, community activists have consistently focused on the harm government officials were inflicting on entire neighborhoods by shutting off water. As the UN had confirmed, Orr's ramped-up shutoff campaign was a gross violation of human rights, and this inherently unjust policy had only been made possible under emergency management. Mass shutoffs were also creating a growing public health crisis, as tens of thousands of residents have been rendered unable to wash clothes and dishes, flush toilets, or bathe themselves, children, and elders (see, e.g., Gross 2017, Recchie et al. 2019). As Charity Hicks emphasized, “There are people who can't cook, can't clean, people coming off surgery who can't wash. This is an affront to human dignity" (Lukacs 2014). Her remarks are echoed by seasoned activist Jim Perkinson: "Those of us involved in trying to remediate the situation are discovering homes with kids who can't drink, homes with elders who can't bathe, homes with patients unable to change wound dressings. Some of them have been without access for as long as a year now" (Perkinson 2014). To make matters worse, child protective services has been authorized to remove children from homes without running water. In addition to a matter of water justice, democracy, and public health, then, Detroit's water crisis raises concerns about reproductive justice, 
particularly given the racial and class dynamics of whose children would be forcefully removed, whose families torn apart and by whom.

As many activists have emphasized, Orr's mass shutoffs were also but the latest episode in a decades-long assault on and attempt to dispossess and displace the Detroit's poorest, predominantly African American residents so that the city could be remade in the images of billionaires, suburban developers, foundations, and far wealthier, mostly white newcomers. The emergency manager law was an important tool in advancing the visions of wealthy elites, wielded skillfully whenever an EM put the interests of bondholders and speculators ahead of the health and well-being of city-dwellers. Emergency management meant that Detroiters were systematically deprived of water all as a direct result of state policies pursued in support of urban "revitalization." As with Flint, it was not just that Detroiters were harmed or how badly they were harmed that needed to be kept in the forefront, but how, by whom, in accordance with what laws and in support of what private interests.

While there were plenty of households in arrears when EM Orr came to power, community organizations such as MWRO had been arguing for years that the main problem was the unaffordability of water in a city where 38 percent of residents live in poverty and the unemployment rate is more than twice the national average. The cost of water and drainage in the city has risen by 119 percent over the past decade, and in July of 2014 alone it rose by 8.7 percent. It is not uncommon for water bills for families of four or more to be around $\$ 150-200$ per month. In a city with an average household income of $\$ 28$, ooo (Smith 2014), this means that some families are forced to set aside 20 percent of their annual income just for water. One fifth of the city's roughly 700,000 residents are paying at least four times the Environmental Protection Agency's (EPA) affordability standard for water and sewerage usage, which recommends that residents be charged no more than 2.5 percent of their annual income.

Water is unaffordable in Detroit, not because certain residents refuse to pay up, but because of the decades-long economic evisceration of the city and the harsh realities of grinding poverty (Sugrue 2005). "Detroit was targeted for disinvestment and political repression because it was a center of power for labor and civil rights," notes scholar-activist Scott Kurashige. "The toxic stew of economic dislocation and racial resentment made the region a breeding ground for all varieties of populism" (Kurashige 2017: 4). Congressman John Conyers, the first elected official to take a stand on Detroit's water crisis, points out that water shutoffs are serving as "a form of collective punishment, victimizing families who are behind on their payments not because of 'behavioral payment patterns,' but because of poverty" (quoted in Howell 2014c). "Full discussion of the situation would require deep analysis of the reasons for so much poverty 
being concentrated in Detroit in the first place, while so much wealth is concentrated in Oakland County next door," notes Perkinson. "It would require telling the story of redlining and racial discrimination in the housing, insurance, and food industries at least," not to mention "the more recent subprime machinations and foreclosures by the banks" (Perkinson 2014).

In the context of capital flight and a rapidly declining tax base, corruption and mismanagement has afflicted Detroit's water department for decades. Contrary to the official narrative, though, it is not city officials who have been in charge of department policy, but federal judges. Between 1977 and 2013, DWSD was under an EPA consent decree because of clean water violations. For most of that time, Federal Judge John Feikens-an open racist and longstanding opponent of integration-held the reigns at DWSD (Wattrick 2011). Through his appointees, union jobs were cut, especially in maintenance and repair, and outsourcing to the private sector became common practice. It was not until March 27, 2013 that US District Judge Sean Cox ordered the return of DWSD to Detroit's EM, ending more than thirty-five years of federal oversight and clearing the way for Orr to begin his mass shutoff campaign.

Under federal oversight, DWSD accumulated more than $\$$ billion in debt, to the point where 50 percent of its 2014 budget was devoted to servicing debts to major banks. Research conducted by the We the People of Detroit Community Research Collective (WPDCRC) confirmed that the largest sources of DWSD debt were not the unpaid bills of residents, which constituted a tiny fraction of the balance sheet. Instead, $\$ 561.1$ million in debt resulted from interest rate swaps (a high-stakes financial gamble gone awry—see Kurashige 2017: 55-57), while another $\$ 576.9$ million resulted from the consequent cancellation of several infrastructure repair projects between 2007 and 2014 (WPDCRC 2016). While Orr claimed that shutting off water to residential customers was necessary to balance the department's books, delinquent corporate accountssome, such as Joe Louis Arena and Palmer Park Golf Course, owing hundreds of thousands of dollars-were not subjected to DwSD's more "rigid" debt collection techniques. Why, then, were Detroit's poorest residents being punished for the failed gambles of department management and the refusal of corporate customers to pay their bills? "When corporations don't pay, there is no mention of the fact and no rebuke," notes Perkinson. "But if poor people of color struggle with bills, then all manner of stereotype and indignant excoriation come rolling to the surface" (Perkinson 2014).

Not only are many Detroiters struggling to pay their bills, but the city as a whole has been disempowered as a result of numerous structural politicaleconomic factors, including state revenue-sharing policy, the emergency manager law, and the nexus of private interests such legislation serves. The denial 
of local representative democracy is among the chief causes of Detroit's water crisis, since it was EM Orr who made the deeply unpopular decision to initiate mass shutoffs in 2014. But this particularly decree needs to be understood in the context of numerous others: "It has been a brutal year for the people of Detroit," writes long-time community activist Shea Howell, as Detroiters have, "seen long cherished rights and values trampled on in the name of financial necessity" (Howell 2013). "Public lands have been given away. Generous tax breaks have been handed to developers, while elders have seen their pensions taxed and slashed," she continues. "People have been threatened. Many have lost livelihood, home, and health care. Schools have been closed. Classrooms are packed. Political cronies line their pockets while abusing our children in academies designed to deaden imagination, connection, and creativity" (Howell 2013).

Community activists have also drawn attention to the city's location next to the Great Lakes, home to 20 percent of the Earth's surface freshwater. When Orr initiated Chapter 9 proceedings in 2013, the city's water system remained one of its most valuable assets. During his tenure as EM, more than 40 private companies reportedly made bids on DWSD. There were also whispers of creating a regional public-private partnership, yet decision-making processes were rendered non-transparent during the bankruptcy. Writing in 2014, Howell suspected that the water crisis "was orchestrated to make the Detroit Water and Sewerage Department more attractive to buyers," and that Orr's "tougher" debt collection measures were "required to convince suburban powers and private speculators the Detroit water system is a valuable asset" (Howell 2014b; 2014a). These suspicions turned out to be well placed: after indicating his support for the creation of a regional water authority, Orr used the threat of privatization to pressure Macomb and Oakland County into finding an acceptable regional solution, resulting in the creation of the Great Lakes Water Authority (GLWA). The form that regionalization has taken remains an ongoing concern vis-à-vis privatization, particularly because of the under-representation of Detroit in the authority's governance (Howell 2019).

The shared perspective of numerous organizations in Southeast Michigan that water is a human right and public trust led to the foundation of the People's Water Board (РWв) coalition in 2008, and has since fueled their struggle to develop a water affordability plan as an alternative to the assistance programs offered by DWSD and GLWA. The particular plan endorsed by the PWB, known 
as the Water Affordability Plan (WAP), assesses the cost for water based on income and ability to pay rather than use. From 2004 to 2005 , MWRO, a founding member of the PWB, collaborated with municipal utilities expert Roger Colton and Michigan Legal Services in crafting an income-based water rate structure, which showed that and how DWSD could create a system in which low-income households pay no more than 2.5 percent of their income for water. The WAP was approved by City Council in 2006, due in part to the support of Councilwoman JoAnn Watson. However, after the water department claimed to have the funds to implement the program, these funds suddenly vanished from the budget and the WAP was replaced by the Detroit Residential Water Assistance Plan (DRWAP). DRWAP provides limited assistance to financially struggling households, and only retroactively, once residents have already fallen into shutoff status (Colton 2005).

Beginning with Kwame Kilpatrick, Detroit's mayor from 2002 to 2008, mayors in Detroit have refused to pursue an income-based model for water providence, arguing that the state's legal framework will not support it (Noble and Ferretti 2019). Instead, Mayor Duggan has helped foster two strands of the official narrative: that Detroiters just don't want to pay for water, and that help is there for those with "legitimate" needs. When Orr turned over operations of DWSD to Duggan following the month-long moratorium won by activists in July 2014, Duggan announced a new 10-Point Plan that he said would aid residents behind on their bills, replacing the ineffective DRWAP. Despite the initial fanfare around Duggan's new plan, its effectiveness has since been thoroughly debunked. In its first year, only 300 of the several thousand customers who qualified were able to keep up with scheduled payments (Guyette 2015a; 2015b).

Since assuming the powers of mayor following the limited restoration of home rule at the end of 2014, Duggan has continued Orr's aggressive shutoff policy. While Duggan was busy selling his 10-Point Plan to the press, the water department announced plans to commence another round of shutoffs in the spring of 2015-a campaign that targeted 800 households per day, affecting upwards of 34,00o customers. Duggan's efforts to support low-income households remain grossly inadequate, yet he continues to block the implementation of an affordability program. Despite the continued failure of Detroit's mayors to rally behind it, the affordability plan designed for Detroit has been hailed nationally as a model approach to issues plaguing urban areas struggling to provide water, and has been the starting point for the adoption of similar policies in Philadelphia, and soon in both Baltimore and Chicago.

In September 2014, the Great Lakes Water Authority (GLWA) was created in the course of the bankruptcy proceedings. With GLWA scheduled to 
commence operations in July 2015, the budget for the newly created regional water authority allocated just $\$ 4.5$ million (o.5 percent of DwsD's annual revenue) to aiding customers behind on their bills. While this meager sum would have been woefully inadequate to need in Detroit alone, the fact that GLWA's regional service area spanned across several counties was not lost on activist social workers, who contested false claims about the extent of help available, balking at Orr's suggestion that, "All Detroiters need to do is call." Volunteers responding to calls for aid on WPD's Water Rights Hotline (1-844-42-WATER) and at the MWRO office shared countless stories of low-income customers who had dialed numerous numbers recommended to them by water department administrators, only to hear dial tones or notices that funds were temporarily unavailable (D-REM 2014). The existence of such funds depended on pools of money that rapidly dried up when the fluctuating generosity of private donors predictably proved an unreliable supplement to budgeted allocations. Since the water department could afford $\$ 5.6$ million to hire a private contractor for shutoffs, its unwillingness to devote comparable resources to helping people get out of shutoff status was striking.

The assistance-based models championed by Duggan and others are premised on ignoring the systemic sources of poverty and the fact of limited and, in some cases, fixed incomes that predictably lead to recurring shutoffs. These vicious cycles force families to make dangerous trade-offs between fulfilling basic needs and meeting regular health-related expenses such as food, childcare, energy use (including heating and cooling), and medical care. As community activists have emphasized for more than a decade, a more effective and sustainable way to remedy the situation is to permanently end the shutoffs, refrain from implementing further assistance programs, and devote serious effort to reviewing and adopting some version of the water affordability programs already underway in major cities across the US. Although we are still waiting to see how well these affordability initiatives work out in practice, Detroit's current policies and programs clearly do not work and it is time to explore an alternative rooted in a fundamentally different way of valuing human life.

\section{Free the Water!}

On November 3, 2014, Detroit natives Antonio Cosme and William Lucka were arrested for allegedly painting "Free the Water" and a large black first on the Highland Park water tower, which stands aloft at the intersection of the I-75 and I-94 highways. Both in their twenties, the duo are members of a 
Southwest Detroit-based hip-hop collective called the Raiz Up, which pursues community-building through art, education, and direct action and is actively involved in several grassroots coalitions in the city. On March 15, 2015, several months after being arrested, Lucka and Cosme were formally charged with malicious destruction of property and trespass upon a key facility, despite the fact that the water tower had been out of use for some time. So, in addition to looking at four years in prison and paying thousands of dollars in fines, the two also faced the possibility of being branded as felons, with all of the trappings of the label—forced to "check the box" on employment applications, denied access to public housing, and so forth.

In his coverage of the case in the Metro Times, reporter Aaron Robertson posed the question many Detroiters were asking: "Why is a city fresh out of bankruptcy paying its lawyers to prosecute two young artists who, according to their attorney, have no previous criminal records, who are accused of felonies and not misdemeanors, and possibly send them to prison for years?" (Robertson 2016). As Cosme and Lucka were well aware, Mayor Duggan had created a special "graffiti task force" soon after taking office in 2014. Within the first three years of the task force's operation, the city had issued well over 3,ooo blight tickets with accompanying fines to owners of residential and commercial buildings that had been subject to "vandalism." If the property owners failed to paint over the graffiti themselves, the city would pay to have it removed before billing the owners upwards of $\$ 1,000$ for the work.

In the Free the Water case, though, there was more at stake than the contested term "blight" or how the city would align itself with respect to graffiti. After all, the artwork just happened to be a timely political statement about water, and it had been placed strategically along a major commuter route. In response to Robertson's "Why?" question, Cosme characterized the city's response as "political theater." "This is not about justice," added defense attorney Robert Mullen, who represented the pair of young artists in court. "I'm not saying that tagging property that you don't own isn't criminal in some sense, but this water tower case is not about crime; it's about politics" (Robertson 2016). Some noted how the painting put a twist on the Republic of New Afrika's (RNA) call to "Free the Land!"- a black nationalist and secessionist slogan that originated in Detroit in the late 196os. The painting also poked fun at officials' blanket characterization of activists as demanding "free water," while owning that demand in a way that pushes beyond calls for "affordability," directly challenging the logic of commodification.

The Free the Water case illustrated the willingness of city officials to abuse their powers for the sake of silencing dissent, once again making plain the indefensibility of their shutoff policy. Duggan's administration seemed to be 
making an example of the two young artists in a desperate attempt to close one of the few remaining windows through which Detroiters could lay claim to public space under conditions of emergency management. As in the case of the Homrich 9, though, the courts proved to be a space not yet completely immune to popular influence. Dozens of friends and comrades packed the courtroom whenever Cosme and Lucka were called to appear for the theater. An art exhibition was organized, press conferences were convened, banners were dropped, and funds were raised to help offset the two defendants' legal fees. Ultimately the pair managed to avoid trials, felony convictions, and jail time. As the final update on the Free the Water Defense Campaign website reports: "Thanks to widespread community support and media coverage, the prosecution agreed to negotiate with Lucka and Antonio. Rather than going to trial, they hammered out an arrangement for 1 year of nonreporting probation and 120 hours of community service each" (Free the Water Defense Campaign 2016).

\section{8}

\section{Flint Healing Stories}

Against the background of denigrating portrayals of city residents as incompetent, corrupt, and incapable of self-governance, sharing personal stories became a central part of the struggle to draw attention to the crises unfolding in Detroit and Flint. Long before the poisoning of Flint's water supply became a national scandal, Flint and Detroit organizers met regularly to discuss shared concerns over the deprivation of local citizenship rights (Howell 2015c; Howell and Stephens 2015; Guzmán 2016). A few weeks after the switch to the Flint River in April 2014, about 40 activists from Flint, Detroit, Highland Park, and Muskegon gathered as part of a statewide network to strategize. The meeting was hosted by Citizens for Highland Park Public Schools (CHPPS) and MWRO (Unpublished Minutes 2014; Ketchum 2015).

While the discussion focused on the dismantling of local democracy, concerns over the connection between emergency management, rising water rates, and shutoffs also emerged. In her report from Highland Park, Marian Kramer of the Highland Park Human Rights Coalition (H P HRC) characterized outrageously high water bills as a tool to drive people out of their homes and enable the privatization of local water systems. As Kramer pointed out, the state legislature had placed water rates and billing policies under the control of EM s. Alice Jennings of the NCBL emphasized the ability of the state to attach outstanding water bills to property taxes, contributing to the tens of thousands of tax foreclosures already decimating communities throughout the region. 
Nayyirah Shariff and Claire McClinton of the Flint Democracy Defense League (FDDL) reported on a press conference where residents appeared with tape over their mouths, having been limited to just 3 minutes each at the end of City Council meetings. Democracy, not water, was their primary concern, though they were fully aware of rising water rates and efforts to cut Flint's ties with DWSD. EM Michael Brown had raised water rates by a stunning 25 percent in the spring of 2012, putting thousands at risk of having their water cut off. In 2014, rates rose by an additional 6.5 percent, bringing the average bill in Flint well over \$10o a month. As Pauli notes, "The FDDL realized that popular discontent over water rates and shutoffs, much like discontent over the selling off of public assets, could be a potent source of opposition to emergency management" (Pauli 2019: 125).

Meanwhile, Flint residents started noticing a change in water quality immediately following the switch to the Flint River. They began sharing evidence and testimony on social media pages such as Flint River Water Support Group less than a month after the switch. In response to growing concerns over waterrelated rashes and illness, the FDDL formed a Water Task Force and, with the help of Detroit activists from WPD, began distributing bottled water in neighborhoods. Over the next few months, while distributing water together in both Detroit and Flint, activists heard dozens of stories of shutoffs, hardships in obtaining drinkable water, as well as diseases and rashes linked to the foul, discolored water flowing from the taps.

As government officials refused to acknowledge Flint residents' complaints for months and months, the emerging coalition accelerated their organizing efforts. In January 2015, they announced a series of public meetings in Flint to develop community-wide strategies, providing a deeply democratic alternative to the officially sponsored, highly paternalistic water forums launched in the same month. While introducing a series of church-based gatherings, Shariff reported that communities were facing plummeting water quality, soaring water rates and the use of police to make arrests for water theft. Flintstones had been receiving boil-water advisories for months, alongside warnings that those in poor health or with compromised immune systems should not consume city water. Chemical treatments were said to be out of balance, yet Flint's EM claimed the water was safe to drink.

Public meetings provided the background for a larger strategy of sharing personal stories to raise awareness and counter the dehumanizing logic of neoliberalism, which casts non-experts as lacking the credibility to speak truthfully about the quality of the water flowing from their taps, let alone about the state of their own health and well-being. This strategy was supported by the Michigan Roundtable for Diversity and Inclusion (MRDI), who organized 
statewide "Healing Stories" to address race and class-based disparities in the region. Debra Taylor, a Flint native and Detroit activist with WPD, was the main organizer for the first event. "Many people that I know personally there seem to all have at least a $\$ 200$ water bill per month," she said. "So you've got these extremely high water (bills), and then you're afraid to drink the water" (WCMU 2015).

Over 100 people attended the event. Community activists and leaders from Detroit and Flint served as designated listeners for storytellers hailing from Flint, who worked with Taylor to develop a dramatic way of presenting their experiences: before each person spoke, the others on stage would say in unison, "You have the right to remain silent." The storyteller would then respond, "I waive that right" (Ketchum 2015). Shea Howell, a designated "listener," captured some stories in The Michigan Citizen:

The first woman to step forward said that even her cat won't drink the water out of her tap. She had been taken to the hospital after drinking some soup made for her with tap water. She explained that she had gotten a bill for over \$9oo. “So now I am paying for something I don’t drink and paying $\$ 150$ for bottled water a month. I take a shower and I itch. I was dehydrated from soup. But I am not about to lose my home. I have to choose between property tax and water. I'm 72 years old and getting tired, and my cat only has three or four more lives left."

HOWELL 2015a

Another listener, Councilman Eric Mays, moved the next week to have Flint returned to DWSD, and the Flint City Council voted in favor, 7 to 1 . The Council's efforts were immediately rejected by EM Gerald Ambrose, who said: "It is incomprehensible to me that seven members of the Flint City Council would want to send more than $\$ 12$ million a year to the system serving southeast Michigan." Ambrose claimed definitively that, "Flint water is safe" (Howell 2015a).

Taylor continued as the main organizer of "Healing Stories" efforts while Monica Lewis-Patrick, a fierce water warrior and CEO of WPD, served as host. In July 2015, they held a second event focusing on water, where people were invited to share stories of the illnesses they were developing from consuming contaminated liquids. Reflecting on the importance of this process, McClinton emphasized that, "They were able to tell their stories in a community setting, not alone or in isolation" (Guzmán 2016). The connections established through public storytelling supported ongoing efforts to build relationships and capacities for self-organization among city residents 
across Southeast Michigan. While delivering thousands of gallons of bottled water door-to-door in Detroit and Flint, Lewis-Patrick observed: "Flint [activists] came down to not only support us and encourage us but also to share their stories of contaminated water." At a meeting in July 2014, McClinton and Shariff arrived in Detroit with water samples. As Taylor pointed out, "It looked like ice tea. They told us it came from their taps. I said, 'Come on, really? This is from your tap?' " (Guzmán 2016). These jugs of poison became symbols of the depth of the disregard for public health embodied in emergency management.

Although concerns about lead in the water dated back as far as February 2015 , it would be months before the details of lead and other water-borne contaminants in Flint began to emerge. As local and national media attention continued to focus on Detroit, activists from both cities kept weaving together stories from across the region and beyond. The sharing of these stories from city to city functioned in part as consciousness-raising, helping to overcome the internalization of dominant narratives of victim-blaming (i.e., "it's your own fault if you can't afford to pay for water") and gaslighting (i.e., "there's nothing wrong with the Flint water-residents' perceptions cannot be trusted"). Those sharing their own stories with one another were well positioned to chart the connections between shutting off water and delivering liquid poison. Both resulted from the decisions of EM s, which were made possible by broader statewide efforts to undermine democracy, wrest power from city-dwellers, and escalate the dispossession of low-income, predominantly African American communities.

\section{International Social Movements Gathering}

From May 29 to 31, 2015, Detroit hosted The International Social Movements Gathering for Affordable Water and Housing (International Social Movements Gathering 2015). The event was organized by a coalition of organizations and spearheaded by Alice Jennings of NCBL and Maureen Taylor of MWRo. $35^{\circ}$ people from 47 states and 10 countries attended: residents of Detroit, Highland Park, Flint, and Benton Harbor met with activists from across North, Central and South America, Europe, and First Nations. In addition to film screenings, collective meals, and a water ceremony, conversations focused on sharing experiences from neighborhoods where water access was threatened, along with stories of collective resilience and resistance, proposals for citizen-led policy initiatives, community-based research projects, and organizing and mobilizing in the streets (Howell 2015b). 
It was a powerful gathering. Public storytelling played a central role once again, this time as part of broader efforts to forge solidarity between locallybased activists and those visiting from abroad. Conversations focused on the situation in Michigan quickly expanded and deepened as connections were established between water-insecure communities across the US and globally: people enduring droughts in California, families in Appalachia struggling with heavily contaminated water sources, people in Mexico resisting a 22year effort to privatize local water systems, and communities in Italy resisting attempts by multinational corporations to undermine a referendum that recognized water as a common good. In addition to expanding and strengthening networks of solidarity, the gathering also galvanized resistance in Michigan. The connections between Detroit and Flint were further clarified and emphasized as new relationships were built between organizers from both cities. Melissa Mays stood up in a packed room, held up bottles of brown water and reported:

We were switched by our Emergency Manager from Detroit water to the Flint River which is disgusting and contaminated ... We have been forced to drink, bathe and cook with contaminated water. As a response ... [w]e are being poisoned. I am sick. I have copper poisoning and lupus, all developed since October. All of my children have been to the doctor for rashes, hair loss, and muscle and bone pain. We are fighting a huge health crisis in Flint ... We have no rights. They don't want us here.

PEOPLE'S TRIBUNE 2015

Against the background of government officials in denial-promising insufficient assistance without addressing the core problem of unaffordability, and "guaranteeing" the safety of water that was obviously toxic-participants spoke countervailing truths in clear, plain language. By fortifying resistance efforts across Southeast Michigan, and situating them in the global context of seizures of water and public infrastructures from low-income communities, the Social Movements Gathering positioned activists well to work as a unified front against attacks on community water security throughout the region.

\section{Detroit to Flint Water Justice Journey}

Growing out of conversations initiated at the Social Movements Gathering, activists organized a 70-mile, eight-day walk from Detroit to Flint, dubbed the Detroit to Flint Water Justice Journey for Clean and Affordable Water. 
Sponsored by the Michigan Coalition for Human Rights (MCHR), PWB, MWRO, and others, the group walked 10 miles per day from July 3 to 10, 2015, stopping in several towns along the way to hold public gatherings, rallies, and conversations (MCHR 2015a). The walk began with a spiritual ritual led by indigenous water walkers, convened at the Underground Railroad monument on the Detroit riverfront. From there, the main walkers carried a mixture of water with samples drawn from the Great Lakes and donated by indigenous comrades. Following a send-off rally at the Spirit of Detroit Statue, the first stop was for a Cultural Celebration at Nandi's Knowledge Café in Highland Park, with live drumming, spoken word poetry, a community speak-out, and art-making for people of all ages. Children painted flags with images depicting the significance of water in sustaining all life forms, which were then sewn into a banner to be displayed throughout the walk. Walkers then attended a Town-Hall Meeting and Rally at St. Luke's A.M.E. Church, where people from Highland Park, MI, described how they were facing multiple years of not receiving water bills at all, only to finally receive impossibly high ones, have their water shut off, and face the removal of their children by social services.

Concluding the first day, the Detroit Light Brigade organized an action at dusk in Ferndale, MI, where the message "Clean, Affordable Water Now!" was displayed in lights for all passersby at Woodward Ave. and 9 Mile Rd. to see. Over the following days, the walkers proceeded up Woodward towards Flint, stopping to participate in a service at Birmingham United Church in Bloomfield Hills, MI, a Cross-County Speak-Out at the Baldwin Center in Pontiac, MI, and then on to the cities of Clarkston, Holly, Grand Blanc, and finally, Flint. The journey concluded on July 10, 2015 with a huge rally at Flint City Hall, after which two busses full of people departed for the state capitol in Lansing to deliver a petition demanding safe, affordable water for all.

The Water Justice Journey allowed for conversations among people directly experiencing water shutoffs and exposure to toxic water, who could share how their daily lives had been affected while also speaking to their tremendous capacities to provide care and be cared for by family and neighbors. One woman attended the Flint rally with a jug of brown water drawn from her tap and a fistful of hair that had fallen out after weeks of ingesting the water (Azikiwe 2015). The walk further developed solidarity between Detroit and Flint activists as we built new networks of churches, organizations, and groups along the way. One major goal of the walk was to counter widespread perceptions of Detroit and Flint as disconnected and alone in facing waterrelated problems. The information packet distributed throughout the walk linked together three major problems: mass water shutoffs, unaffordable water, and toxic, unhealthy, dangerous water. It also highlighted two corresponding 
demands: (1) implement the 2005 WAP ("Assistance is not Affordability"); and (2) provide clean, healthy water relief to the people of Flint (Samartino 2015). The organizers insisted that water unaffordability and deprivation in Detroit and water contamination in Flint must be understood in relation and rectified together, connected as they are to the same underlying problems: sacrificing the basic needs of people in pursuit of profit, prioritizing private interests over the people's good, and seizing control of land and resources maintained by predominantly African American communities.

\section{Grassroots Journalism and Filmmaking}

In the face of false, dehumanizing narratives advanced by city and state officials, developing and documenting the story of the impact of mass water shutoffs on the lives of Detroiters became the job of activists, independent filmmakers, and community-based journalists. Community news and radical publications told the story of the shutoffs. Tweets and articles were shared on social media. \#WageLove became the preferred hashtag, in memory of beloved Detroit community leader and water rights activist Charity Hicks. Kate Levy, a Detroit activist and videographer, began documenting everyday efforts to organize and resist shutoffs in Detroit. Combining interviews with people who had been disconnected along with city officials and activists, Levy started weaving together a powerful visual narrative of shutoffs and their impacts, as well as direct actions and other forms of resistance. Activists staged viewings of her work throughout the city and suburbs to share the stories of fellow Detroiters. Short clips were shared on social media and mainstream newscasts (Levy 2015a, 2015b, 2015c, 2016a, 2016b; The Raiz Up 2015).

Over the next few months, Levy's filmmaking skills were joined with the investigative reporting of Curt Guyette. A long-time Detroit reporter covering grassroots politics, Guyette was hired by the American Civil Liberties Union (ACLU) to provide a critical perspective on the bankruptcy. By the time the UN convened the Town Hall Meeting in October 2014, Levy and Guyette had compiled a wide array of visual and narrative evidence demonstrating that water shutoffs were happening with complete disregard for the health and well-being of Detroiters and were often conducted in haphazard, patently disrespectful and irresponsible ways (Levy and Guyette 2015c). Levy and Guyette also revealed the Duggan administration's inability to grapple seriously with the underlying problems of poverty, municipal debt, and the financialization of urban governance. They documented the inadequacy of assistance plans, showing that, of the 3,000 people enrolled in Duggan's 10-Point Plan, only 300 
were able to meet scheduled payments and stay enrolled for a year (Guyette 2015a, 2015b; Levy and Guyette 2015c). Through their work we met young people defending their neighbors from disconnections by standing on shutoff valves, refusing to move (The Raiz Up 2015); elders living on fixed incomes being forced to return to the water department multiple times with forms to prove their medical needs for water, or gathering rainwater in barrels for cooking and bathing; and mothers organizing entire days around securing bottled water for children (Levy 2015a). These images started to chip away at the legitimacy of EM s, Mayor Duggan, DWsD, and all who defended Detroit's shutoff policy.

Flint community activists such as Claire McClinton, Nayyirah Shariff, Melissa Mays, and LeeAnn Walters played pivotal roles in bringing the Flint water crisis to light, forcing the powers that be to officially acknowledge it as such and return the city to Detroit water in October 2015 (Shariff 2015; Guyette 2016a; Guzmán 2016). It was their work, combined with that of Levy and Guyette, that was largely responsible for drawing national attention to the unfolding disaster and its connections with Detroit (Guyette 2015c, 2015d, 2015e; Levy and Guyette 2015a, 2015b, 2015d, 2016). Both the ACLU of Michigan website and Levy's site, www.detroitmindsdying.com were widely circulated, providing up-to-date news and images. Videos produced by Levy and Guyette were also regularly incorporated into reports by independent news outlets such as Democracy Now! and picked up by mainstream pundits such as Rachel Maddow.

As the region moved closer to launching the GLWA and KWA, a coalition of Detroit and Flint-based organizations orchestrated a series of actions designed to challenge the narratives and policies advanced by state officials, underscore the relationship between the two cities, and further strengthen regional solidarity. The first step was a press conference held at the ACLU offices in Detroit on January 15, 2016 (Levy 2016a). The discussion focused on undermining the idea advanced by Duggan, DwSD Director Gary Brown, and other officials that it was "illegal" to implement water rates adjusted to household income. By convening legal experts from a variety of organizations, the coalition shifted the idea of "criminality" away from those who could not afford to pay for water, or who were turning water back on to meet basic needs, and on to those being paid to turn water off. Attorneys Mark Fancher of NCBL, Julie Hurwitz of the National Lawyers Guild (NLG), Thomas Stephens of D-REM, and Peter 
Hammer of the Damon J. Keith Center for Civil Rights presented a series of briefs supporting the legality of an income-based water program. As the briefs made clear, not only is an income-based rate structure legal in Michigan, but it would likely generate more revenue for DWSD while addressing public health concerns raised by mass water shutoffs. "The water affordability plan is not only legal, it is the only right thing to do," said Hurwitz. "It is in the public interest to ensure that not only affordable water but safe water be provided to our community" (Guillen 2016). News accounts of the conference revealed glaring weaknesses in the official narrative and nervous shifting on the part of state officials.

The press conference was followed the next day by a Teach-In emphasizing connections between Detroit and Flint (D-REM 2016a, 2016b, 2016d). Both cities were framed as struggling against EM s whose job it is to balance budgets at the expense of public health and welfare. The Teach-In on Detroit and Flint Water Crises was convened at the Damon J. Keith Center for Civil Rights at Wayne State University on January 16, 2016. A packed house welcomed Flint activists Melissa Mays, Nayyirah Shariff, and Laura Sullivan as they shared news and analysis of the unnatural disaster back home, reminding everyone in the room that the I-75 runs both ways, "from Flint to Detroit and back again." Members of the Homrich 9 invited attendees to consider what it means to engage in civil disobedience under emergency management. As Rev. Bill Wiley-Kellermann of St. Peter's Episcopal Church in Detroit reminded us, "civil disobedience involves breaking an unjust law," such as Jim Crow laws in the South. However, "in a situation where the unjust law is an Emergency Manager law, which takes over the entire structure of governance, the act of civil disobedience needs to be to become ungovernable."

The Teach-In also provided a forum for sharing the work of communitybased researchers and modeling the creation of citizen-led policy initiatives. Everyone received a reader filled with stories of collective resistance, analyses of laws and policies, and independent journalism produced by Flint and Detroit activists. After learning about water affordability from Maureen Taylor and Sylvia Orduño of MWRo, participants were among the first to learn of the groundbreaking research conducted by the We the People of Detroit Community Research Collective (WPDCRC). Monica Lewis-Patrick, Emily Kutil, and Gloria Aneb House facilitated a discussion of an ongoing research project the collective had taken on, known at the time as, simply, "The Mapping Project." In August 2016, the results of the project's first phase were unveiled in the same space with the launch of a collaboratively-crafted manuscript, Mapping the Water Crisis: The Dismantling of African-American Neighborhoods in Detroit: Volume One (WP DCRC 2016). The statistical evidence 
gathered throughout the project helped set the stage for the unveiling of the Water is a Human Right Bill Package, which, as State Representative Stephanie Chang explained in her presentation, was a product of decades of dedicated work by a broad-based coalition hailing from Detroit and Flint (Chang and Garrett 2016).

The Teach-In was followed the next week by a People's Tribunal, held in the sanctuary at the Cass Corridor Commons on January 23, 2016 (D-REM 2016c, 2016e). Both events attracted hundreds of people. The People's Tribunal for Violations of the Human Right to Water was a social justice theater project developed by activists to inform the general public concerning the crises that have been created by mass water shutoffs in Detroit, and the criminal negligence that led to the poisoning Flint's water supply. In this trial, the people of Detroit indicted Mayor Duggan (played by Michael Doan), Governor Snyder (Fred Vitale), and EM s Kevin Orr and Darnell Early (who were said to be in their cells) for violations of the human right to clean, safe, affordable water. The indictments were drafted by lawyers for the people, with the role of prosecutor enacted by Attorney William Goodman of the NLG. The witnesses for the people were Detroit's Valerie Jean Blakeley and Debra Taylor, followed by Melissa Mays and Nayyirah Shariff of Flint. The jury was comprised of respected community leaders hailing from both cities, including Claire McClinton, William M. Davis, Elena Herrada, William Copeland, Teresa Kelly, and Rudy Simons.

The trial proceedings were orchestrated as a moral drama featuring testimony from people who had faced shutoffs and exposure to contaminated water. The judge (Wiley-Kellermann) argued that all levels of government, including the courts, had either failed us or been rendered powerless under emergency management, "necessitating a People's Tribunal." Drawing a sharp contrast with the judicial system's inability to act on behalf of the people, he offered pointed instructions to the jury: "Ordinarily, judges instruct jurors in a way that actually minimizes, constricts, and constrains their awareness of their own power. I will not do so. Juries are inherently a powerful and authoritative form of direct democracy. I will not hide that fact from you" (D-REM 2016e). Finally, the judge offered these words in closing:

Mr.s Snyder, Duggan, (Early, and Orr), you are hereby stripped of your authority to lead or rule the people of Detroit and Michigan. The people are no longer bound to honor you in office. Moreover, you are to be lead in an ignominious spectacle of your failures before the people of Michigan, the people of the nation, and the people of the world. Go. You are no longer over us. Let it be so ordered. Taps gavel. 
The press conference, Teach-In, and Tribunal were all held as Governor Snyder's failure to respond to the poisoning of Flint's water began to make national headlines. As people across Michigan were waking up to the pivotal role played by EM s in creating the water crises in Flint and Detroit, the Tribunal helped inspire the creation of an Unwanted Poster featuring a mug shot of Snyder, put together by the Beehive Design Collective in collaboration with local activists (D-REM 2016f). Within days the poster could be seen hanging on public buildings from Ann Arbor to Lansing, and from Flint to Detroit. It was also proudly displayed on stage at a reprise of the Tribunal, held at Detroit's Charles H. Wright Museum of African American History on February 16, 2016. Mark Fancher of NCBL joined Monica Lewis-Patrick of WPD and several other activists on a panel. "The issues of race and class are clear," read the flyers for the event, "as no one can imagine affluent, mostly white communities being forced to use contaminated, rash-inducing, lead-poisoned water as is the case in Flint. Likewise, it is no coincidence that massive water shutoffs have been used against an overwhelmingly African American city in the case of Detroit" (Black Bottom Archives 2016). Speaking to a reporter from The Detroit News, Lewis-Patrick emphasized that, "It's just as much a danger here [in Detroit] not to have water as having poisoned water." Gloria Aneb House of D-REM clarified the intent of the gathering as follows: "We hope that more and more of us will be mobilized to stand against this" (Hicks 2016).

Driving home to Detroit along the I-75, a bumper sticker captures our attention: "Five Years \& Counting, Flint is Still Broken." It beggars belief that a city so close to the Great Lakes could still have undrinkable water. How could Flint still be in the midst of a crisis created by the poisoning of its water by policy? How could it be that Detroit continues to violate the human rights of its residents through systematic water deprivation? When could these interrelated crises be declared over, and by whom?

From the perspective of Detroit's water warriors, justice for Detroiters could not be achieved through the declaration of another temporary moratorium, tougher crack-downs on corporate customers, or the implementation of better assistance programs. Nor was the limited restoration of home rule at the end of 2014 enough to ensure that similar crises would not erupt whenever state officials decided to declare another "financial emergency." Since the state created the Michigan Financial Review Commission to ensure that future mayors would remain faithful to the dictates of EM s for the next thirteen years, state 
receivership in Detroit is not really over, anyway, having "continued by other means" (Kurashige 2017: 70-71). At this point it cannot even be said that representative democracy has been restored at the municipal level, let alone deeper forms that would give city-dwellers genuine control over the operations of public utilities.

Despite the claim of state and city officials that there was never a water "crisis" to begin with in Detroit, waves of shutoffs continue as inadequate assistance programs keep failing those struggling to survive poverty. In yet another distressing development, in late August 2018, less than a week before the start of classes, the discovery of water-borne lead contamination in more than fifty of Detroit's public schools led to Detroit's Community School District announcement that drinking water would be shut off in all school buildings. As community activists have emphasized all along, recovery from Detroit's water crisis would have to involve a definitive end to the shutoffs, the adoption of a water affordability program, and the total abolition of emergency management. More broadly, it would require a serious reckoning with a longstanding history of racial and class antagonisms expressed spatially as an urban-suburban conflict over critical infrastructure, resources, and bargaining power. Since there is no previous state of amicable relations to which residents of city and suburbs can be restored, new relations must instead be forged by all those committed to upending the dehumanizing logics of racial capitalism and colonization.

In terms of accountability for Detroit's water crisis, the list of individuals and institutions would need to include everyone involved in creating and maintaining the practice of emergency management, from Governor Snyder on down to the crafters of right-wing policy that meet annually on Mackinac Island. Then there are the media pundits who have either unthinkingly echoed or carefully defended Orr and Duggan's proclamations and justifications of the shutoffs; local elected officials and administrators who, even when stripped of their powers, refused to publicly oppose the shutoffs, wasting their positions of influence; public health officials and researchers who failed to join NUN and others by officially declaring the shutoffs a public health emergency, and to prioritize the health and well-being of Detroiters even when this would have meant risking their political careers; private contractors who continue to make millions by executing shutoffs; and more broadly still, residents of surrounding suburbs who benefit from inequitable rate structures and from having gained greater control over critical infrastructure through emergency management. Without taking account of the broader historical context of the shutoffs, though, Detroit's current situation cannot be adequately understood. Nor can we afford to forget that the actions of individuals and organizations continue to be constrained and enabled by background legal frameworks, such 
as emergency management. Until the historical, systemic roots of Detroit's water crisis have been addressed, it cannot truly be declared "over."

Five years out, many Flint residents continue to express legitimate concerns that certain water quality issues are not being adequately addressed, that little has been done to fix the overall problem, properly understood, and that what has been done has been carried out largely by state officials and agencies- the very people who caused the crisis in the first place. Official disregard for the health and well-being of Flintstones continues as the officials responsible for creating and maintaining the crisis continue to evade legal accountability. As of April 6, 2018, the state is no longer providing bottled water to Flint residents, leaving many people reliant on point-of-use filters that remain an ongoing health concern, particularly due to the threat of bacterial contamination. While some of the city's pipes have been repaired or replaced, the massive work of laying down new water distribution infrastructure-from municipal service lines to privately owned pipes—is far from complete and sorely lacking in official support.

As in Detroit's case, how and by whom Flint's water crisis is framed matters a great deal to whether and when an "end" could be declared. While state officials have been quick to depict Flint's as strictly a lead-in-water-situation, community activists have been clear from the jump that the crisis is not only about lead, but everything else that residents have been forced to endure since the switch to the Flint River. The sources of residents' suffering include the human and property-related harms of lead and other water-borne contaminants; the costs of removing toxic substances and bacteria from the municipal water system; the costs of addressing various illnesses linked to contaminated water, not to mention the heavy psychological toll associated with having one's water poisoned by the very officials one had empowered to safeguard public health, and the profound disruption of daily routines entailed by all of the above.

In connection to the exclusive or excessive focus on lead, Flint's water crisis has often been misrepresented as a water treatment problem-a framing that obscures its inherently political dimensions. Yet as Pauli points out, "If missteps around corrosion control and regulatory failures were at fault, the state could get away with sacrificing some of its low-ranking bureaucrats to popular demands for accountability and placing the rest of the blame on the EPA." Moreover, "because the pipes could be 'healed' through orthophosphate treatment (a notion that became the object of much scorn and ridicule on the ground in Flint), the state could argue that replacing them gradually—or even not at all—would not compromise public health" (Pauli 2019: 60). Depicting the crisis in strictly technical terms has allowed Snyder and Flint's EM s to avoid accountability for their role in creating and maintaining the crisis. While 
there are undoubtedly systemic dimensions to the problem, Flint activists have emphasized that individual actors, such as Snyder, are squarely to blame, in addition to various government agencies that failed to safeguard public health. Calls to arrest Snyder are not symbolic. They are urgent demands for retributive justice that have yet to be met, underscoring the multifaceted "brokenness" of the existing political system.

Beyond demands for retributive justice, reparations for the harms the state has inflicted on Flint cannot be achieved through the distribution of point-ofuse filters, or even the continued provision of free bottled water, important though these measures undoubtedly are in meeting immediate needs. While there may be no reparative gesture adequate to the damage done and the irreplaceable losses suffered, Flint activists have been clear that repairing what state agents and agencies broke would have to involve the replacement of damaged infrastructure, a refund in water bills dating back to April 2014, and full funding to meet the health and education needs of all those exposed to contaminated water. Were a federal disaster to finally be declared in the city (not just an "emergency" of the sort declared by Obama), recovery money and efforts would no longer need to be routed through the state and federal agencies could work directly with communities who have long been active on the ground.

For years Flint and Detroit activists have emphasized that while systematic water poisoning and deprivation are clearly human rights issues, both are deeply local issues too. By insisting that "Flint Lives Matter" and "Whose water? Our water!" water warriors have consistently underscored that the questions of how and with whom recovery efforts are organized is centrally important, not just whether some sort of recovery occurs. "What kind of say would residents have over how resources coming into the city were managed?" asks Pauli in Flint's case. "Who would get to decide when Flint had been made 'whole'?" (Pauli 2019: 223). Prioritizing the political self-determination of Flintstones and Detroiters makes the question of local democracy a crucial measure not only of whether each city is being made whole, but how - by and with whom. Contrary to the colonialist logics of state officials, the knowledge and ways of knowing of local people matter. Ongoing water struggles raise the question of to what extent residents of Detroit and Flint are managing to achieve some semblance of epistemic self-determination in the wake of rampant state interference into local affairs, and also given the limitations of representative forms of democracy as respecters of the knowledgeable participation of citizens (Doan 2018).

The question of local democracy — whether it can be said to exist, and in what form-links Flint and Detroit together. For Flintstones, the suspension 
of local representative democracy was chiefly to blame for the water crisis, as the decisions to switch to the Flint River and approve the KwA project would never have been made were it were not the ability of EM s to ignore the opinions of residents and their elected representatives (see Hammer 2016). Nor would local elected officials have implemented Orr's mass water shutoff campaign and sold out Detroiters through the creation of GLWA. Emergency management engenders utter disregard for public health, local knowledge, and popular will. Restoration of local democracy and the abolition of emergency management are preconditions for fixing what has been broken. Yet as Pauli emphasizes - and much the same could be said in Detroit's case-struggles over water and democracy in Flint are not strictly defensive, for water warriors also carry another world in their hearts. The fight for justice in Flint "would not be over until democracy was a reality: not just in the negative sense of freedom from emergency management, but in the positive sense of a community of people empowered to take charge of their water, their infrastructure, their health, their city, and their future" (Pauli 2019: 48). Community activists have enlivened "a more radical democratic vision, one that [seeks] to deepen democracy by building off the popular energies liberated by the crisis, the grassroots associations formed in response to it, and the new political consciousness sparked by it" (6). That vision remains to be realized. The struggle for another world continues.

\section{References}

AlHajal, K. (2014). "Detroit Mayor Given Control Over Water Department Amid Shutoff Controversy." M-Live. July 29, 2014. Available at: https://www.mlive.com/news/ detroit/2014/o7/detroit_mayor_given_control_ov.html (consulted July 29, 2019).

Azikiwe, A. (2015). "Detroit to Flint Water March Ends." Worker's World. July 18, 2015. Available at: http://www.workers.org/2015/07/18/detroit-to-flint-water-marchends/\#.V7-PK5MrKRs (consulted December 15, 2016).

Black Bottom Archives. (2016). "Water Crimes Tribunal." Available at: http://www. blackbottomarchives.com/calendar/2016/2/16/water-crimes-tribunal (consulted December 15, 2016).

Blue Planet Project (врР). (2014). "Submission to the Special Rapporteur on the Human Right to Safe Drinking Water and Sanitation Regarding Water Cutoffs in the City of Detroit, Michigan." July 18, 2014. Available at: http://www.blueplanetproject. net/wordpress/wp-content/uploads/Detroit-HRTW- submission-June-18-2014.pdf (consulted December 15, 2016). 
Chang, S. and Garrett, L. (2016). "All Michiganders Deserve Clean Water." Detroit Free Press February 2, 2016. Available at: http://www.freep.com/story/opinion/contributors/2016/o2/o2/all-michiganders-deserve- clean-water/79641244/ (consulted December 15, 2016).

Colton, R. (2005). "A Water Affordability Program for the Detroit Water and Sewerage Department (DWSD)." Available at: https://drive.google.com/file/d/ oBy2p2ytUJwFzRyıVazFhVGlzQTQ/edit (consulted December 15, 2016).

Cramer, J. (2015). "Race, Class, and Social Reproduction in the Urban Present: The Case of the Detroit Water and Sewage System." Viewpoint Magazine. October 31, 2015. Available at: https://viewpointmag.com/2015/10/31/race-class-and-social-reproduction-in-the-urban-present-the-case-of-the-detroit-water-and-sewage-system/ (consulted December 15, 2016).

Detroiters Resisting Emergency Management (D-REM). (2014). "Notes from the United Nations Town Hall Meeting at Wayne County Community College in Detroit on 10/ 19/2014 from 4-6pm." DREM. October 20, 2014. Available at: http://www.d-rem.org/ notestranscript-from-the-un-town-hall-meeting/ (consulted December 15, 2016).

Detroiters Resisting Emergency Management (D-REM). (2016a). Teach-in on Detroit and Flint Water Crises, January 16th, followed by People's Tribunal, January 23rdjoin us! d-rem. January 7 , 2016. Available at: http://www.d-rem.org/teach-in-ondetroit-and-flint-water-crises-january-16th-followed-by-peoples-tribunal-january23rd-join-us/ (consulted December 15, 2016).

Detroiters Resisting Emergency Management (D-REM). (2016b). "Teach-in on Detroit and Flint Water Crises." d-rem. January. Available at: https://www.scribd.com/doc/ 295470015/Detroit-and-Flint-Water-Struggles-Readings-and-Resources (consulted December 15, 2016).

Detroiters Resisting Emergency Management (D-REM). (2016c). "New Location for People's Tribunal on Saturday, January 23!” d-rem. January 18, 2016. Available at: http://www.d-rem.org/new-location-for-peoples-tribunal-on-saturday-january23rd/ (consulted December 15, 2016).

Detroiters Resisting Emergency Management (D-REM). (2016d). "January 16 Teach-in on Detroit and Flint Water Crises: Reader, Presentation, and Bill Package." d-rem. January 19, 2016. Available at: http://www.d-rem.org/january-16-teach-in-on-detroitand-flint-water-crises-reader-and-presentation/ (consulted December 15, 2016).

Detroiters Resisting Emergency Management (D-REM).(2016e). "The People's Tribunal on Water Crimes-Judge's Script.” d-rem. January 28, 2016. Available at: http:// www.d-rem.org/the-peoples-tribunal-on-water-crimes-judges-script/ (consulted December 15, 2016).

Detroiters Resisting Emergency Management (D-REM). (2016f). “\#ArrestSnyder WANTED poster from Beehive Collective." d-rem. February 4, 2016. Available at: http://www.d-rem.org/arrestsnyder-wanted-poster-from-beehive-collective/ (consulted December 15, 2016). 
Doan, M.D. (2018). "Resisting Structural Epistemic Injustice." Feminist Philosophical Quarterly 4(4): 1-24. Available at: https://ojs.lib.uwo.ca/index.php/fpq/article/ view/6230/4987 (consulted July 29, 2019).

Ferretti, C. and Pardo, S. (2014). "Orr Defends City Water Shut-Offs." The Detroit News. July 17, 2014. Available at: [broken link] (consulted July 29, 2019).

Finley, N. (2014). “There is No Right to Free Water." The Detroit News. July 18, 2014. Available at: http://www.economicpolicyjournal.com/2014/o7/there-is-no-right-tofree-water.html (consulted December 15, 2016).

Free the Water Defense Campaign. (2016). "Settlement Negotiated!" Free the Water Defense Campaign. October 24, 2016. Available at: https://freethewater313.wordpress.com/2016/10/24/settlement/ (consulted July 29, 2019).

Gross, A. (2017). "Experts See Public Health Crisis in Detroit Water Shutoffs." Detroit Free Press. July 26, 2017. Available at: https://www.freep.com/story/news/local/michigan/detroit/2017/o7/26/detroit-water-shutoffs/512243001/ (consulted October 22, 2019).

Guillen, J. (2016). "Legal Experts: Detroit Can Reduce Water Rates for the Needy." Detroit Free Press. January 15, 2016. Available at: http://www.freep.com/story/news/ 2016/o1/15/legal-experts-detroit-can-reduce-water-rates-needy/78852696/ (consulted December 15, 2016).

Guyette, C. (2015a). "With Detroit's Water Payment Plan a Massive Failure Mayor Duggan Plans Changes." aclu of Michigan. April 18, 2015. Available at: http://www.aclumich. org/democracywatch/index.php/entry/with-detroit-s-water-payment-plan-a-massive-failure-mayor-duggan-plans-changes (consulted December 15, 2016).

Guyette, C. (2015b). "Detroit's Water Tug-of-War." Detroit Metro Times. June 3, 2015. Available at: http://www.metro-times.com/detroit/detroits-water-tug-of-war/ Content?oid=2348110 (consulted December 15, 2016).

Guyette, C. (2015c). "Flint Water Crisis a Bitter Indictment of Dysfunctional Emergency Manager." The Michigan Chronicle. October 7, 2015. Available at: http://michronicleonline.com/2015/10/o7/flint-water-crisis-a-bitter-indictment-of-dysfunctionalemergency-manager/ (consulted December 15, 2016).

Guyette, C. (2015d). "Flint Water and the No Blame Game." Michigan Democracy Watch Blog. October 15, 2015. Available at: http://www.aclumich.org/democracywatch/ index.php/entry/flint-water-and-the-no-blame-game (consulted December 15, 2016).

Guyette, C. (2015e). "Flint's State of Emergency is a Sign that Democracy is Working There Again." The Guardian. December 16, 2015. Available at: https://www.theguardian.com/commentisfree/2015/dec/16/flint-state-of-emergency-sign-democracy-isworking (consulted December 15, 2016).

Guyette, C. (2015f). "Judge Calls Detroit's Prosecution of Water Shut-Off Protesters a 'Disaster." Detroit Metro Times. December 23, 2015. Available at: http://www.metrotimes.com/detroit/judge-calls-detroits-prosecution-of-water-shut-off-protesters-adisaster/Content?oid=2387489 (consulted December 15, 2016). 
Guyette, C. (2016). “Power of the People." Detroit Metro Times. February 24, 2016. Available at: http://www.metro-times.com/detroit/power-by-the-people/Content?oid=2397708 (consulted December 15, 2016).

Guzmán, M. (2016). "Water Warriors: How Four Activists Let the World Know About Water Crises in Flint and Detroit." Sojourners. May 25, 2016. Available at: https:// sojo.net/articles/water-warriors (consulted December 15, 2016).

Hammer, P.J. (2016). "The Flint Water Crisis, KWA, and Strategic-Structural Racism: A Reply to Jeff Wright, Genesee County Drain Commissioner and CEO of Karegnondi Water Authority." Written testimony submitted to the Michigan Civil Rights Commission. December 31, 2016. Available at: https://www.michigan.gov/documents/mdcr/Hammer_Reply_Flint_MCRC_Testimony_123116_552226_7.pdf (consulted October 22, 2019).

Hicks, M. (2016). “Activists Speak Out on Flint, Detroit Water Issues." The Detroit News. February 16, 2016. Available at: http://www.detroitnews.com/story/news/local/ michigan/2016/o2/16/activists-speak-flint-detroit-water-issues/80489336/ (consulted December 15, 2016).

Howell, S. (2013). "Distorted Reality." The Boggs Blog. July 15, 2013. Available at: http:// boggscenter.org/distorted-reality-by-shea-howell-week-67-of-the-occupation-ofdetroit/ (consulted July 29, 2019).

Howell, S. (2014a). "Water, Dispossession, and Resistance." The Boggs Blog. June 10, 2014. Available at: http://boggscenter.org/water-dispossession-and-resistance-byshea-howell-by-shea-howell/ (consulted July 29, 2019).

Howell, S. (2014b). "Water Choices.” The Boggs Blog. July 4, 2014. Available at: https:// conversationsthatyouwillneverfinish.wordpress.com/2014/o7/04/water-choicesby-shea-howell-week-65-of-the-occupation/ (consulted July 29, 2019).

Howell, S. (2014c). "Beyond the Bottom Line." The Boggs Blog. July 8, 2014. Available at: https://conversationsthatyouwillneverfinish.wordpress.com/2014/07/13/beyond-thebottom-line-by-shea-howell-week-66-of-the-occupation/ (consulted July 29, 2019).

Howell, S. (2015a). "Flint Water Stories." d-rem. March 29, 2015. Available at: http:// www.d-rem.org/thinking-for-ourselves-flint-water-stories/ (consulted December $15,2016)$.

Howell, S. (2015b). "Gathering Waters." d-rem. May 31, 2015. Available at: http://www.drem.org/thinking-for-ourselves-gathering-waters/ (consulted December 15, 2016).

Howell, S. (2015c). "Flint and Lead." The Boggs Blog. September 7, 2015. Available at: https://conversationsthatyouwillneverfinish.wordpress.com/2015/og/27/flint-andlead-by-shea-howell/ (consulted December 15, 2016).

Howell, S. (2019). "Resisting Emergency Management." Liquid Utility. April 29, 2019. Available at: https://www.e-flux.com/architecture/liquid-utility/262537/resistingemergency-management/ (consulted July 29, 2019). 
Howell, S. and Stephens, T. (2015). “Toxic Twins: Emergency Management and Flint River Water." People's Tribune. May. Available at: http://peoplestribune.org/pt-news/ 2015/o5/toxic-twins-emergency-management-and-flint-river-water/ (consulted December 15, 2016).

Howes, D. (2014). “Targeting Water Scofflaws Fair, Long Overdue." The Detroit News. July 11, 2014. Available at: http://www.detroitnews.com/article/20140711/BIZ/307100100/ 1322/BIZ/Targeting-water-scofflaws-fair--long-overdue (consulted December 15 , 2016).

International Social Movements Gathering. (2015). "International Social Movements Gathering, May 29-31, 2015 in Detroit, Michigan." Available at: http://www.socialmovementsgathering.info/ (consulted December 15, 2016).

Ketchum, W.E. (2015). "Community Members Share Thoughts, Revelations, and Encouragement at Flint Healing Stories." M-Live. March 21, 2015. Available at: http:// www.mlive.com/entertainment/flint/index.ssf/2015/o3/community_members_ share_though.html (consulted December 15, 2016).

Kirkpatrick, O.L. and Breznau, N. (2016). "The (Non)politics of Emergency Political Intervention: the Racial Geography of Urban Crisis Management in Michigan." Mimeo, SMU. Available at: http://papers.ssrn.com/sol3/papers.cfm?abstract id $=2754128$ (consulted December 15, 2016).

Kurashige, S. (2017). The Fifty-Year Rebellion: How the U.S. Political Crisis Began in Detroit. Oakland, CA: University of California Press.

Lambert, L. (2014). “U.S. Bankruptcy Judge Allows Detroit Water Shutoffs to Continue." Reuters. September 29, 2017. Available at: https://www.reuters.com/article/us-usadetroit-water/u-s-bankruptcy-judge-allows-detroit-water-shutoffs-to-continueidUSKCNoHO1DS2O140929 (consulted July 29, 2019).

Levy, K. (2015a). "Detroit Minds Dying." Available at: http://www.detroitmindsdying. com/ (consulted December 15, 2016).

Levy, K. (2015b). "Disorder in the Court." Available at: https://vimeo.com/149346o62 (consulted December 15, 2016).

Levy, K. (2015c). "Bill Wiley-Kellermann's Closing Arguments in District CourtHomrich 9 Trial, December 2015." d-rem. December 30, 2015. Available at: http:// www.d-rem.org/homrich-9-trial-bill-wylie-kellermans-closing-arguments-in-district-court/ (consulted December 15, 2016).

Levy, K. (2016a). "Watch: January 15 Press Conference on Water Affordability." d-rem. January 18, 2016. Available at: http://www.d-rem.org/watch-january-15-press-conference-on-water-affordability/ (consulted December 15, 2016).

Levy, K. (2016b). "Eastside Payment Center, May 2016." d-rem. Available at: http:// www.d-rem.org/watch-dwsd-assistance-fair-at-eastside-payment-center-230ooshutoffs-on-deck/ (consulted December 15, 2016). 
Levy, K. and Guyette, C. (2015a). "Hard to Swallow: Toxic Water Under a Toxic System in Flint." aclu of Michigan. June 25, 2015. Available at: https://www.youtube.com/ watch?v=L4ngZeDuhdU (consulted December 15, 2016).

Levy, K. and Guyette, C. (2015b). “Corrosive Impact: Leaded Water \& One Flint Family's Toxic Nightmare.” aclu of Michigan. July 9, 2015. Available at: https://www.youtube. com/watch?v=27K54-lV-Z4 (consulted December 15, 2016).

Levy, K. and Guyette, C. (2015c). "Drops in the Bucket." Available (consulted 15 December, 2016) at: https://www.youtube.com/watch?v=ywzicIRVYoc.

Levy, K. and Guyette, C. (2015d). "Circle of Lies: Dodging Blame for the Flint River Disaster." aclu of Michigan. October 29, 2015. Available at: https://www.youtube. com/watch?v=qEWBGE31qCY (consulted December 15, 2016).

Levy, K. and Guyette, C. (2016). "Here's to Flint." aclu of Michigan. March 6, 2016. Available at: https://vimeo.com/157922510 (consulted December 15, 2016).

Lewis-Patrick, M. and Cabbil, L. (2014). "On Water Issues, It's Detroit Versus the U.N." The Detroit News. November 6, 2014. Available at: http://www.detroitnews.com/ story/opinion/2014/11/o6/water-issues-detroit-versus-united- nations/18553431/ (consulted December 15, 2016).

Lukacs, M. (2014). "Detroit's Water War: A Tap Shut-Off That Could Impact 300,000 People." The Guardian. June 25, 2014. Available at: https://www.theguardian.com/ environment/true-north/2014/jun/25/detroits-water-war-a-tap-shut-off-thatcould-impact-300ooo-people (consulted July 29, 2019).

Michigan Coalition for Human Rights (MCHR). (2015). "Join Us as We Walk from Detroit to Flint and Demand Clean, Affordable Water for All!" mchr. June 29, 2015. Available at: http://www.mchr.org/2015/o6/join-us- as-we-walk-from-detroit-toflint-and-demand-clean-affordable-water-for-all/ (consulted December 15, 2016).

Michigan Welfare Rights Organization (MWRO) and People's Water Board Coalition (РWв). (2014). "Media Advisory: UN Human Rights Commission Will Hear Michiganders' Testimony." d-rem. October 14, 2014. Available at: http://www.d-rem. org/media-advisory/ (consulted December 15, 2016).

Noble, B. and Ferretti, C. (2019). "Detroit Could Be Losing Out on Millions Under Water System Lease." The Detroit News. January 14, 2019. Available at: https://www.detroitnews.com/story/news/local/detroit-city/2019/o1/14/detroit-losing-out-millionsunder-flawed-water-system-lease/2548568002/ (consulted July 29, 2019).

Pauli, B. (2019). Flint Fights Back: Environmental Justice and Democracy in the Flint Water Crisis. Cambridge, MA: MIT Press.

People's Tribune (2015). "International Social Movements Gathering on Water and Affordable Housing, Detroit, MI." People's Tribune. July. Available at: http://peoplestribune.org/pt-news/2015/o6/international-social-movements/ (consulted December $15,2016)$. 
Perkinson, J. (2014). "Why I Choose to Block Detroit's Water Shutoff Trucks." Sojourners. July 21, 2014. Available at: https://sojo.net/articles/why-i-choose-block-detroitswater-shutoff-trucks (consulted July 29, 2019).

Rall, A. (2018). "Community Organizing and the Detroit Water Struggle: Report from the Front Lines." Journal of Progressive Human Services 29(2): 103-129.

The Raiz Up. (2015). "In Detroit, Private Demolition Company Shuts Off Water to Pregnant Woman during Ramadan." The Raiz Up. Available at: https://vimeo.com/ 132829920 (consulted December 15, 2016).

Recchie, J., Recchie, A., Powell, J.A., Lyons, L., Hardaway, P., and Ake, W. (2019). Water Equity and Security in Detroit's Water \& Sewer District. Haas Institute for a Fair and Inclusive Society, University of California, Berkeley: Berkeley, CA. Available at: haasinstitute.berkeley.edu/detroitwaterequity (consulted October 22, 2019).

Robertson, A. (2016). "As the City Zeroes in on Graffiti, Two Detroit Artists Face Possible Prison Time." Detroit Metro Times. September 21, 2016. Available at: https://www. metrotimes.com/detroit/as-the-city-zeroes-in-on-graffiti-two-detroit-artists-facepossible-prison-time/Content?oid=2465406 (consulted July 29, 2019).

Samartino, R. (2015). "Water Justice Journey Platform/information Sheet." $p w b$. Available at: https://www.scribd.com/doc/303202449/Water-Justice-JourneyPlatform-Information-Sheet (consulted December 15, 2016).

Scorsone, E.A. (2014). Municipal Fiscal Emergency Laws: Background and Guide to State-Based Approaches (Working Paper 14-21). Washington, DC: Mercatus Center, George Mason University.

Shariff, N. (2015). "Lead in Drinking Water: Do Flint Lives Matter?" People's Tribune. Available at: http://peoplestribune.org/pt-news/2015/11/lead-in-drinking-water-doflint-lives-matter/ (consulted December 15, 2016).

Smith, H. (2014). "Four Things You Should Know About Detroit's Water Crisis." Grist. Available at: https://grist.org/cities/the-4-things-you-should-know-about-detroitswater-crisis/ (consulted July 29, 2019).

Sugrue, T. (2005). The Origins of the Urban Crisis: Race and Inequality in Postwar Detroit. Princeton, NJ: Princeton University Press.

United Nations Office of the High Commissioner for Human Rights (OHCHR). (2O14). "Detroit: Disconnecting Water From People Who Cannot Pay-An Affront to Human Rights, say UN experts." OHCHR. Available at: http://www.ohchr.org/EN/NewsEvents/ Pages/DisplayNews.aspx?NewsID=14777\&LangID=E (consulted December 15, 2016).

Unpublished Minutes. (2014). Statewide Anti-EMF Network Meeting, Highland Park, mi, 4 May.

Wattrick, J. (2011). “Despite Remembrances, Judge John Feikens' Legacy is Clouded by Water System Oversight." M-Live. May 17, 2011. Available at: https://www.mlive.com/ news/detroit/2011/05/despite_remembrances_judge_joh.html (consulted July 29, 2019). 
wCMU Public Radio News. (2015). "Flint Grassroots Groups Address Inequity Through Stories." WCMU. Available at: http://wcmu.org/news/?p=14276 (consulted December 15, 2016).

We the People of Detroit Community Research Collective (WPDCRC). (2016). Mapping the Water Crisis: The Dismantling of African-American Neighborhoods in Detroit, Vol. One. Detroit, MI: Conklin Creative.

Wiley-Kellermann, B. (2017). Where the Water Goes Around: Beloved Detroit. Eugene, OR: Cascade Books.

Williams, C. (2017). “Trial Dismissed Against 'Homrich 9' Water Protesters.” The Detroit News. June 21, 2017. Available at: https:/www.detroitnews.com/story/news/local/ detroit-city/2017/06/21/homrich-case-dismissed/103087798/ (consulted July 29, 2019).

Williams, P. (2014). “Drop Dead, Detroit!” The New Yorker. January 19, 2014. Available at: https://www.newyorker.com/magazine/2014/o1/27/drop-dead-detroit (consulted July 29, 2019). 


\section{Author Queries}

\section{chapter 7}

AQ1: Please note that the cross-reference "Checker (2012)" has not been provided in the reference list. Please provide the same.

AQ2: Please note that the cross-reference "MCHR (2015a)" has not been provided in the reference list. Please provide the same. 